\title{
The Correlation of the Age and Length of Stay with the Compliance of Beef Cattle Farmers Norms (Case Study) in Final Waste Disposal of Jatibarang, Semarang City
}

\author{
Krismiwati Muatip*, Hermin Purwaningsih, Agus Priyono, Muhammad Nuskhi, \\ Lucie Setiana and Aditya Permana Putra \\ Faculty of Animal Science, Jenderal Soedirman University, Purwokerto 53122, Central Java, Indonesia \\ *Corresponding author email: krismiwati@gmail.com
}

\begin{abstract}
The study was conducted in the final waste disposal (FWD) Jatibarang, Kedungpane, Mijen, Semarang. A survey was conducted, targeting the beef cattle farmers who pastured their cattle in the TPA Jatibarang, Semarang. The observed variables were age (X1), education background (X2), length of stay (X3), total cattle owned (X4), and the farmer's norm compliance (Y1). Purposive sampling was used to determine the sample of regions. Total respondents were determined by simple random sampling, selecting 70 out of 350 farmers (20\%). The result of the analysis showed that $78.57 \%$ farmers were at their productive age (2055 years old), $64.30 \%$ had elementary education background, $74.29 \%$ had been farming for over 14 years, and $62.86 \%$ had fewer than seven cattle. The farmers also showed a sound moral compliance. The result of spearman rank showed a non-significant correlation between age and length of farming experience with norm compliance. Age was negatively correlated with norm compliance, but education background and total cattle owned were significantly correlated with norm compliance, showing a correlation value of 0,248 and 0,610 , respectively.
\end{abstract}

Key words: age, education background, length of farming experience, the number of cattle owned, farmer's norm compliance, final waste disposal

Abstrak. Penelitian ini dilaksanakan di Tempat Pemrosesan Akhir (TPA) Jatibarang, Kelurahan Kedungpane, Kecamatan Mijen, Kota Semarang. Metode yang digunakan adalah survey dan sasaran penelitian yaitu peternak sapi potong yang menggembalakan sapi di TPA Sampah Jatibarang Kota Semarang. Variabel yang diamati adalah umur (X1), pendidikan (X2), lama tinggal (X3), dan jumlah sapi potong yang dipelihara (X4) serta kepatuhan norma peternak (Y1). Penetapan sampel wilayah secara sengaja (purposive sampling). Penetapan jumlah responden menggunakan simple random sampling sebanyak 70 peternak dari 350 peternak (20\%). Hasil analisis menunjukkan sebanyak $78,57 \%$ peternak dalam kategori berumur produktif (20-55 tahun) dan sebanyak 64,30 \% berpendidikan Sekolah Dasar. Lama beternak sapi potong lebih dari 14 tahun $(74,29 \%)$ dan jumlah pemilikan sapi potong yang terbanyak adalah $<7$ ST $(62,86 \%)$. Peternak memiliki kepatuhan norma yang cukup hingga baik. Hasil analisis rank spearman menunjukkan terdapat hubungan yang tidak nyata antara umur dan lama beternak dengan kepatuhan norma peternak. Ada kecenderungan Umur berkorelasi negative dengan kepatuhan norma. Pendidikan dan jumlah ternak yang dimiliki peternak berhubungan nyata dengan kepatuhan norma dengan nilai korelasi masing-masing sebesar 0,248 dan 0,610.

Kata kunci: umur, pendidikan, lama beternak, jumlah kepmeilkan sapi potong, kepatuhan norma peternak, tempat pemrosesan akhir

\section{Introduction}

Beef cattle farming in the final waste disposal (TPA) Jatibarang, Semarang has been existing for the past 25 years. It started as the government's establishment for the farmers who lost their farming land for building the TPA. As a compensation, the government gave 37 cows to 16 family living in RW IV community group in Kedungpane, Mijen,
Semarang in 1993. The current cattle population has reached approximately 500 . The farmers who receive the cattle have to return 2 calves in two consecutive calvings to the government, who will distribute the return calves to other community member who have not received cattle. The process is repeated until all the members in the society group receive cow. 
Covering an area of 46.18 ha, TPA Jatibarang is extensively used by the farmers living in RW IV for pasturing their cattle. The TPA is a beneficial for farmers to provide forage. The interaction between the farmers and the society in the surrounding TPA leads to the formation of the commonly acknowledged regulations or norms. Norms are a set of behavior - determined and applied by the majority of a society - to govern human interaction, from the formal to personal relation. Also, norm is established by the major group of people in a community (Conte et al., 2013). The norms are developed to govern all human interactions, from the most formal to the most intimate. Norms in a society are based on daily life values, religion, culture and the existing law. Norms are the concrete realization of values that sets the obligation for the people. In other words, norms set out the mechanism of justifiable conduct to uphold the values (Mawardi, 2007). The norms can be used as the parameter of deviant or acceptable set of behavior in the society (Said, 2013). Compliance to the norms enables the society to reach the shared goals (Mutiawardhana, 2013).

The commonly acknowledged norms become the parameter of conduct within the society. The regulation and sanctions are the reasons for the society members to avoid deviant conducts. Older individuals tend to be more obedient to the prevailing norms than the younger ones because they have a mature mindset. For breeders who have a large number of cattle in the category will try to adjust to the existing norms so that the business is safe as well as the livestock business cannot be separated from environmental support. Likewise, the length of stay of a person in an area makes the person familiar with the prevailing norms so that they will be more obedient. Social norms are incorporated into Indonesian education alongside science.
The purpose of this study was to determine the age (X1), education (X2), length of stay (X3), number of beef cattle kept (X4) and breeder's compliance (Y1), also determine the relationship between the age $(\mathrm{X} 1)$, education $(\mathrm{X} 2)$, length of stay (X3), and number of beef cattle kept (X4) with compliance with breeder's norms (Y1).

\section{Materials and Methods}

The study targeted the farmers who pasture their beef cattle in the area of TPA Jatibarang, Kedungpane, Mijen, Semarang. Survey method was applied, observing variables including age (X1), education background $(X 2)$, length of stay $(X 3)$, the number of cattle owned (X4), and the farmer's moral compliance (Y1). Total respondents were determined by simple random sampling, selecting $20 \%$ of the total 350 farmers, i.e. 70 farmers as the sample. Data were subject to descriptive analysis using Spearman Rank correlation to identify the correlation and to test the significance of assosiative hypotheses when each connected variable was in ordinal scale (Sugiyono, 2010). In this study, Spearman's correlation was used to identify the correlation between age, length of farming experience, and total cattle owned by the farmers with compliance to the norms.

\section{Results and Discussions}

\section{Description of Farmer's Age}

Farmers' age refers to the age when the farmers started farming beef cattle in TPA Jatibarang, Semarang (in year). In this study, the youngest was 31 and the oldest was 79, with an average of 51 years old and categorized into productive age and postproductive age or the elderly (Table 1 ). According to Haloho et al. (2013), 20-55 years belong to the group of productive age, while below 20 is not productive (school-age). Above 55 years old marks the declining productivity, linear to the aging (post- 
productive). Respondents in productive age have a more mature perspective to make decision and obey the rules.

Beef cattle farming in TPA Jatibarang has been established for over 25 years by the society in the surrounding area, especially in the community group named RW IV in Kedungpane district, Mijen. The venture has brought impact on leveraging the farmer's knowledge and income in livestock maintenance. Farmers with a longer farming experience have a better livestock management because of the learning-by-doing process. According to Raharjo et al. (2018), the length of time a person spend in livestock businesses can affect the ability of the individual to better manage livestock businesses, because the longer a person run the business, the more skillful and knowledgable he become, and it could stimulate better making decisions to get optimal results.

Based on Table 2, $74.29 \%$ of the beef cattle farmers have been running the business for over 14 years. Some farmers obtained the beef cattle on the first batch 25 years ago as a compensation of TPA building in Kedungpane, Mijen. The length of experience results in a beneficial skill for the farmers to develop their farming ventures. According to Hendrayani et al. (2009), farming/livestock experience is an essential factor for a successful farming business. Farming experience is closely related to the skills; the longer the experience, the higher the skills.

Education is one of the factors that affect people's knowledge. Education is a processwhere someone starts to embrace all aspects of knowledge. Level of education background determines the ability to perceive new information or knowledge that the person is yet to posess. Makatita (2013) explained that an individual with knowledge and skills can better harness the inner and outer potentials. As such, farmer's education background affects their way of thinking and level of acceptance to innovation and new technology.

Based on Table 3, most farmers (64.3\%) had primary education background, followed by middle school (17.14\%), high school $(15.7 \%)$ and the least was Associate degree $(2.86 \%)$. It is evidenced that the education background of farmers in TPA Jatibarang was relatively low. It was related to economic factors and a stigma that both educated and non-educated people would eventually earn money. Therefore, the farmers made a choice to run beef cattle farming on top of their main profession as a scavenger. Low level of education made the farmers difficult to perceive information or to share information to other farmers due to limited communication skill. Hendrayani et al. (2009)

Table 1. Category of farmer's age

\begin{tabular}{lcc}
\hline Category & Total (people) & Percentage (\%) \\
\hline Productive (20 - 55 years) & 55 & 78.57 \\
Post-productive (>55 years) & 15 & 21.43 \\
\hline
\end{tabular}

Source: Primary data (2017)

Table 2. Length of experience in beef cattle farming

\begin{tabular}{lcc}
\hline Category & Total (people) & Percentage (\%) \\
\hline$<8$ years & 6 & 8.57 \\
$8-14$ years & 12 & 17.14 \\
$>14$ years & 52 & 74.29 \\
\hline Total & 70 & 100
\end{tabular}


Table 3. Level of education background of beef cattle farmers in TPA Jatibarang

\begin{tabular}{lcc}
\hline Formal education & Farmers (people) & Percentage (\%) \\
\hline Primary School & 45 & 64.30 \\
Middle School & 12 & 17.14 \\
High School & 11 & 15.70 \\
Associate degree & 2 & 2.86 \\
\hline Total & 70 & 100
\end{tabular}

Source: Processed primary data (2018)

Table 4. The number of cattle owned in livestock TPA Jatibarang

\begin{tabular}{lcc}
\hline Animal Unit $(\mathrm{AU})$ & Total respondent (people) & Percentage (\%) \\
\hline$<7$ & 44 & 62.86 \\
$7-11$ & 22 & 31.43 \\
$>11$ & 4 & 5.71 \\
\hline Total & 70 & 100 \\
\hline
\end{tabular}

Source: Primary research data (2018)

stated that the higher the education level, the higher the ability to perceive technology and innovation, and vice versa. The longer the farmers pursue education, the better their rationale. Farmers with Middle School and High School level of education would find it easier to accept technology innovation in livestock, at both individual and group level. In addition, Sudana and Subagyono (2012) stated that the chance to adopt the technology of Comprehensive Plant Management (PTT) was higher when the farmers were younger and had a higher education background.

Total cattle refer to the cattle owned by the farmers. According to Krisna and Harry (2014), cattle ownership refers to the number of cattle managed by the farmers in one period of management. Total cattle are the success indicator of livestock business (Table 4).

Table 4 indicates that $62.86 \%$ of beef cattle farmers in TPA Jatibarang Semarang were included in low category (fewer than 7 cattle owned). The result of the research reported three farmers who owned 70 beef cattle but were not incorporated in the research so that the data were evenly distributed.

The number of cattle owned in this research was expressed in animal unit (AU). Animal Unit is the measure used to correlate cattle body weight and feed intake. The calculation of Animal Unit according to Directorate General of Livestock Indonesia (2015) is as follow: 1 cow = $1 \mathrm{ST}$; 1 bull = $1 \mathrm{ST}$; 1 young bovine, $>1$ year $=0.5 \mathrm{ST} ; 1$ calf $=0.25$ ST.

According to Yusdja (2005), owning 1-9 cattle/farmer in Bali cattle farming belongs to small-scale livestock.

\section{Description of Norm Compliance among Farmers in TPA Jatibarang}

Norms are a set of regulations acknowledged in a region to reach a shared convenience and goals. As stated by Cahyono (2014), norm compliance is a shared value that acts as a parameter of conduct based on the existing regulation and sanction. Also, norms are a binding rule to the members of society as a control of conduct according to the relevant values (Steven, 2002). Every region upholds its own norms that may be different to one another due to the diverse purposes and interests.

The norms applied in beef cattle farming in TPA Jatibarang refer to the social norms that regulate the farmer's social life. In this study, observance of norms was observed about matters that relating to beef cattle business. Norm compliance is categorized into three: deviate, moderately conform, and conform (Table 5). 
Tabel 5. Level of norm compliance among the beef cattle farmers

\begin{tabular}{lcc}
\hline Category & Farmers (people) & Percentage (\%) \\
\hline Deviate & 0 & 0 \\
Moderately conform & 28 & 40.00 \\
Conform & 42 & 60.00 \\
\hline
\end{tabular}

Source: Primary data (2018)

Beef cattle farmers in TPA Jatibarang are the residents of RW IV Kedungpane district who were mainly waste collectors. Scavenging habit that produces an immediate cash from the transaction has made these waste collectors entrust the beef cattle (government establishment) to friends or neighbors as a 'feedlot' for about three months. However, the success of friends or neighbours to fatten the cow has changed the perspective of farmer-waste collector to conduct beef cattle farming.

Norm compliance of farmers in TPA Jatibarang Semarang was included in moderately conform (40\%) and conform (60\%). A high norm compliance was due to the ability of group leader to ensure the farmers that the regulations were set to alleviate interaction in the society. For example, the leader organized the batch of cow establishment. The government set a rule that every farmer who received one cow would have to return two calves which would be given to the other members of society in the next batch who were not included in the first batch. However, the leader tended to prioritize his family members for the next batch, which inspired other farmers to follow suit.

The farmers conformed to the norms because they have been residing in RW IV for 41 years in average. The shortest residency was 5 years and the longest was 64 years. The length of stay in a place would result in an intensive interaction and produce the shared and acknowledged rules and norms. The rules are usually internalized in the society instead of written in a pact; however, the rules act as a parameter of conduct in social relationship that imposes a sanction to any deviation. Social norms determine the strength of individual relations because it stimulates social cohesiveness that brings positive impact on society development (Sulaeman et al., 2015).

A study by Sulaeman et al. (2013) concluded that the internal factors of community that play role in society empowerment were leadership and social capital. The role of leadership in society empowerment is to disseminate information, set examples, raise awareness, motivate, provide guidance, generate targets and people, and facilitate and allocate resources. The leaders in TPA Jatibarang Semarang had a significant impact on society living around the TPA. One rule stated that only residents of RW IV areallowed to raise and pasture beef cattle in TPA. The chief of RW IV that used to hold a double position as the farmers group leader harnessed an authoritative mode of leadership. Although the farmers group are currently inactivem the leadership impact remains strong. The leader profile in TPA Jatibarang also held an important role in cattle selling; therefore, the regulations and norms proposed by the leader was faithfully obeyed by the farmers. Despite the authoritative mode of leadership, the long-term interaction has allowed the community to understand the character of each individual. Trang (2013) stated that the leader who had a close relationship with the members created a comfortable and friendly environment in an event.

The leader was considered to contribute to beef cattle establishment in RW IV; therefore, the farmers paid a high respect to the leader. Also, the leader required the members to 
contribute financially - Rp 1000/month. Various sanctions for rule violation include a warning and a double monetary contribution. The money was used for a shared interest such as burying the dead cattle due to road accident. It was in line with Suradisastra (2016) that a leader could determine a sanction for the members who violated the regulation.

The farmers sold the cattle through a broker who sold them in animal markets out of town. The logic behind using a broker was to conceal the origin of the cattle. The society has known that the beef cattle maintained in the TPA Jatibarang produced meat that were not ASUH (safe, healthy, complete, and halal); therefore, they sold it to the broker. The farmer group leader/chief of RW also played role as a broker. The farmers should have quarantined the cattle for three months before selling them to ensure the ASUH quality.

Not all farmers could build a cage for the cattle due to the limited piece of land. Therefore, the farmers pasture the cattle in TPA Jatibarang all day. This practice violated the government rule that the cattle should be pasturing during the day and night so the cattle would not disturb the TPA workers. Furthermore, the cattle would be safer in the cage at night. Seventy percent of farmers in this study set a cage behind or beside their house.

In general, the farmers could not identify their own cattle pastured in the TPA. The farmers only knew the total cattle they owned. As a result, hundreds of cows were pasturing in the heaps of garbage in TPA Jatibarang. The farmers would call the cow home by hitting wood planks together around the cage. Oftentimes, some cows found its way to the wrong cage.

Farmers who did not have a cage would let the cattle pasture in the TPA all day and night. To maintain safety of the cattle and the neighborhood, the farmers and society would take turn in controlling or securing the perimeter. This regulation was set up based on the awareness of both society and farmers for their shared interests.

\section{The Relationship Between Farmer's Characteristics and Norm Compliance}

Spearman's Rank was used to identify the correlation between farmer's characteristics and norms compliance (Table 6).

Based on Table 6, there was a nonsignificant correlation between age and norm compliance. The tendency showed that the older the farmers, the more non-compliant they became. The older farmers might feel they had lots of knowledge and sufficient life experience; therefore, they tend to reject the norms that collided with what they have experienced or believed. Furthermore, the older farmers perceive the leader as younger than them, so they were not obliged to follow the rules. The problematic life around the TPA has made the farmers become stubborn. The result of this study was not in accordance with that of Faqih (2011) who reported that the more experienced farmers tend to be more compliant to the norms. On the other hand, as someone gets older, their physical fitness and way of thinking tend to decline, so they tend to violate the rules. The older farmers might feel they had enough knowledge and life experiences, so they tended to reject the

Table 6. Result of analysis of spearman's rank

\begin{tabular}{lc}
\hline Variables & Norm compliance \\
\hline Age & -0.024 \\
Education & $0.248^{*}$ \\
Length of farming experience & 0.121 \\
Animal Unit & $0.610^{*}$
\end{tabular}

Note: * significant correlation 
norms that were incompatible with their core values. Furthermore, the older farmers perceived the leaders as younger than them, so they did not feel obliged to obey the rules set by the leader. The complex life in the TPA neighbourhood has made the farmers obstinate. However, this finding was in contrary with Faqih (2011) who reported that as someone gets older, he becomes more experienced and compliance to the regulation. Disobedience of the older farmers may due to their being stubborn. However, as someone gets older, his physical capability and mindset tend to decline. In addition, Baba et al. (2011) stated that the older the person, the lower his participation to the norm compliance due to the perceived self-experiences. Besides age, education background also affected perception on compliance to norm regulation (Baba et al., 2011). The result of study on beef cattle farmers in TPA Jatibarang Semarang showed that farmer's background study was significantly correlated with the level of norm compliance. Farmer's education background could alleviate their heart to obey the acknowledged norms within the community.

The length of farming experience did not significantly affect the farmer'ss norm compliance. The farmers have practiced the beef cattle farming in TPA for a long time, because they were the first to receive beef cattle as a compensation from the government. However, they refused to accept some government programs for the TPA such as the construction of a factory near the TPA to turn organic waste into fertilizer. The program was, in fact, a solution from several studies claiming the quality of meat from beef cattle pastured in the final waste disposal was questionable (not clean, healthy, complete and halal). It was evidenced from the content of lead in cow feces that reached $5.5651 \mathrm{ppm}$, and the cadmium was $0.1495 \mathrm{ppm}$. The heavy metals in cow feces is an indicator that the cow has been contaminated with heavy metals (Purwasi et al., 2014). A study by Trisdihar and Dewi (2016) and Masduqi and Ngabekti (2016) also found that the liver of cows pastured in final waste disposal (TPA) Jatibarang, Semarang were contaminated with lead $(\mathrm{Pb})$.

Total cattle owned by the farmers was significantly correlated with norm compliance. Farmers who own many cattle tend to be more compliant to the norms or regulation, because they are dependent to the community leader who acts as the broker for cattle trading. Leadership in local community plays a significant role in establishing the values and norms of local community. Leadership agent also provides direction, and most of the time, may cease the process and progress of social change in the community. The main role of local leadership agent is as the mobilizer of community members, the centre and channel of information and the bearer of other social functions (Suradisastra, 2017). Dewi (2012) stated that leaders have to recognize their leadership style in a process of influencing and directing the activity of the community members, because the success or failure of an organization depends on how well the leader leads. Trang (2013) stated that the leaders who are close to the community members contribute to the comfortable and friendly environment in the communal activity. In order to address the farmer's deviant attitude towards meat quality, the government should raise awareness of the leaders in beef cattle farmer's community about the danger of consuming meat of cows pastured in final waste disposal. The other solution would be relocating the farmers in other area where feedlot was potentially built.

\section{Conclusions}

Most beef cattle farmers in TPA Jatibarang, Semarang were the productive-age population ( $<55$ years old), with education background in primary school level and have been in beef 
cattle farming for over 14 years. The most cattle owned by a farmer was $7 \mathrm{AU}$. The farmer's norm compliance was under the categories of 'moderately compliant' and 'compliant.' There was a not significant correlation between age and the length of farming experience with the norm compliance. However, a significant correlation occurred between education and the number of cattle owned with the norm compliance.

\section{Acknowledgement}

The authors express their gratitude to Universitas Jenderal Soedirman for the reseach grant.

\section{References}

Baba, S., Isbandi., T. Mardika dan Maridin. 2011. Faktor - Faktor yang Mempengaruhi Tingkat Partisipasi Peternak Sapi Perah dalam Penyuluhan di Kabupaten Enrekang. JTTP. 1 (3): 194 - 209. Universitas Hasannudin.

Cahyono, B. 2014. Peran Modal Sosial dalam Peningkatan Kesejahteraan Masyarakat Petani Tembakau di Kabupaten Wonosobo. EKOBIS 15 (1): 1 - 16. Universitas Islam Sultan Agung Semarang.

Conte, R., Andrighetto, G. and Campennl, M. eds., 2013. Minding norms: Mechanisms and dynamics of social order in agent societies. Oxford University Press. Oxford

Dewi, P.S. 2012. Pengaruh Pengendalian Internal dan Gaya Kepemimpinan Terhadap Kinerja Karyawan Spbu Yogyakarta (Studi Kasus pada Spbu Anak Cabang Perusahaan Rb. Group). Jurnal Nominal 1(1): 1-22. Universitas Negeri Yogyakarta.

Faqih, A., 2011. Hubungan Antara Karakteristik Petani dan dinamika Kelompok Tani dengan Keberhasilan Program PUAP. Prosiding SNaPP: Sosial, Ekonomi dan Humaniora, 2(1), pp.309316.

Haloho, R. D., S.I, Santoso., dan Marzuki. 2013. Efisiensi Usaha Peternakan Sapi Perah di Kabupaten Semarang Effort Efficiency Dairy Cattle Farming Semarang Regency. Agromedia. 31 (2): 1 -8. Universitas Diponogoro.

Hendrayani. 2009. Analisis Faktor-Faktor yang Mempengaruhi Motivasi Berternak Sapi di Desa Koro Benai Kecamatan Benai Kabupaten Kuantan Singingi. Jurnal Peternakan. 6 (2): 5362
Krisna, R. dan Harry. 2014. Hubungan Tingkat Kepemilikan dan Biaya Usaha dengan Pendapatan Peternak Sapi Potong di Kabupaten Sukabumi Provinsi Jawa Barat. Jurnal Aplikasi Manajemen. 12 (2):296-304.

Makatita, J. 2013. Hubungan Antara Karakteristik Peternakan Dengan Skala Usaha Pada Usaha Peternakan Kambing di Kecamatan Leihitu Kabupaten Maluku Tengah. Agrinimal, 3 (2): 7883.

Masduqi, M. and Ngabekti, S., 2016. Efek Lama Perendaman Dan Konsentrasi Sari Jeruk Nipis Terhadap Penurunan Kadar Timbal (Pb) Pada Daging Sapi (Studi Kasus Di TPA Jatibarang Semarang). Life Science, 4(1).

Mawardi. 2007. Peranan Social Capital dalam Pemberdayaan Masyarakat. Komunitas Jurnal Pengembangan Masyarakat Islam. 3 (2)151 162. Universitas Gadjah Mada.

Mutiawardhana, R., S. Ermawati dan E. Handryanta. 2013. Model Pemberdayaan Masyarakat Berbasis Peternakan di Daerah Pertanian Lahan Kering Desa Kemijeng Kecamatan Semin Kabupaten Gunungkidul. Tropical Aniamal Husbandry. 2 (1): 41 - 50. Universitas Sebelas Maret.

Purwasi, R.M., Kadir, S. and Abudi, R., 2014. Analisis Kadar Logam Berat (Timbal Dan Kadmium) Pada Feces Sapi Yang Dipelihara di TPA Tanjung Kramat. Kim Fakultas IImu-IImu Kesehatan dan Keolahragaan, 2(2).

Raharjo, S.S., Rahayu, E.S. and Purnomo, S.H., 2018, May. Analisis Keuntungan Usaha Beternak Puyuh di Kecamatan Kokap Kabupaten Kulonprogo. In Prosiding Seminar Nasional Fakultas Pertanian UNS (Vol. 2, No. 1, pp. D-22).

Said, I. 2013. Paradigma Sosial dalam Masyarakat. JURNAL BERITA SOSIAL Jurusan Pengembangan Masyarakat Islam (PMI)/Kessos. 1 (1): 35 - 38. UIN Alauddin Makassar.

Steven, D.E, 2002. The Effects of Reputation And Ethics On Budgetary Slack. Journal of Management Accounting Research. 14 (2): 153171.

Sudana, W. and Subagyono, K., 2012. Kajian faktorfaktor penentu adopsi inovasi pengelolaan tanaman terpadu padi melalui sekolah lapang pengelolaan tanaman terpadu. Jurnal Pengkajian dan Pengembangan Teknologi Pertanian, 15(2).

Sugiyono. 2010. Statistika Untuk Penelitian. Alfabeta. Bandung.

Sulaeman ES, Karsid R, Murti B, Kartono DT, Waryana, Hartanto R. 2013 Leadership, social capital, access to information and community empowerment to address health issues. 
International Journal of Scientific Research and Education (IJSRE). 1 (5): 90-107.

Sulaeman, E.S., Murti, B. and Waryana, W., 2015. Peran Kepemimpinan, Modal Sosial, Akses Informasi serta Petugas dan Fasilitator Kesehatan dalam Pemberdayaan Masyarakat Bidang Kesehatan. Kesmas: National Public Health Journal, 9(4), pp.353-361.

Suradisastra, K, 2017. Dinamika Kelembagaan Masyarakat Lahan Marjinal. Badan Penelitian dan Pengembangan Pertanian. Bogor.

Suradisastra, 2016. Strategi pemberdayaan kelembagaan petani. Forum Penelitian Agro Ekonomi 26(2), pp. 82-91).
Trang, D.S. 2013. Gaya Kepemimpinan dan Budaya Organisasi Pengaruhnya terhadap Kinerja Karyawan (Studi pada Perwakilan Bpkp Provinsi Sulawesi Utara). Jurnal EMBA 1 (3):208-216. Universitas Sam Ratulangi.

Trisdihar, A.I. and Dewi, N.K., 2016. Penyerapan Timbal (Pb) Pada Hati Sapi Menggunakan Daun Jambu Biji (Psidium Guajava L.)(Studi Kasus di TPA Jatibarang). Life Science, 4(1).Wheelan, S.A., 1993. Group Process: A Development Perspective. Ally \& Bacon. Amerika.

Yusdja, Y. 2005. Kebijakan Ekonomi Industri Agribisnis Sapi Perah di Indonesia. Jurnal Analisis Kebijakan Pertanian.Vol.3(3). 